
\title{
28 Resarch Soure \\ Dry sliding tribology of carbon fibre reinforced ceramic matrix composites with variation of laminate orientation and surface conformity
}

PARSHANT KUMAR ( $\square$ parshantkumarjmd@gmail.com )

Indian Institute of Technology BHU Varanasi https://orcid.org/0000-0002-7182-1645

Vjay Kumar Srivastava

Indian Institute of Technology BHU Varanasi

\section{Research Article}

Keywords: Ceramic matrix composite, carbon, electron microscopy, wear testing

Posted Date: April 10th, 2020

DOI: https://doi.org/10.21203/rs.3.rs-22010/v1

License: (c) (1) This work is licensed under a Creative Commons Attribution 4.0 International License.

Read Full License 


\section{Abstract}

Tribological behaviour of composites depend upon the surface conformity of interacting surfaces, local friction and wear response, and interaction area proportion of its constituents. Several other factors like wear debris interaction with the contact surfaces, and braking energy are also involved during in-service conditions. For laminated composites, interaction area proportion and wear debris interaction change with the orientation of laminates, due to change in surface conditions. Earlier research on tribological behaviour of carbon/carbon (C/C) and carbon/carbon-silicon carbide (C/C-SiC) composites mostly dealt with the parallel orientation of the laminates, and fully conformal surfaces. Thus, present article aims to investigate the tribological behaviour of $\mathrm{C} / \mathrm{C}$ and $\mathrm{C} / \mathrm{C}-\mathrm{SiC}$ composites with variation of laminate orientation, surface conformity, normal load and sliding velocity. Normal and parallel orientation of laminates were considered with low and non-conformal Hertzian contacts. Worn surfaces were analysed under scanning electron microscope. The results show more fluctuations in friction coefficient (COF) for normal orientation of laminates. C/C-SiC composites loaded with parallel orientation of laminates generally exhibited highest COF and lowest wear loss. COF and wear loss decreased in non-conformal Hertzian contacts when compared with low conformity contacts and the reduction was large for $\mathrm{C} / \mathrm{C}$ composites as compared to $\mathrm{C} / \mathrm{C}$-SiC composites.

\section{Introduction}

Carbon/Carbon (C/C) composites exhibit low density $\left(\sim 1.6-1.98 \mathrm{~g} / \mathrm{cm}^{3}\right)$ and excellent thermal, mechanical and tribological properties, due to which $\mathrm{C} / \mathrm{C}$ composites are considered as promising candidates for high temperature structures of aircrafts [1, 2]. In contrast to metals and ceramics which show decrease in strength, $\mathrm{C} / \mathrm{C}$ composites show increase in strength with increase in temperature [3]. $\mathrm{C} / \mathrm{C}$ composites are very much sensitive to humidity and show unstable friction behaviour in humid environment [4]. Their oxidation resistance is also low $[5,6]$. Thus the high cost, low oxidation resistance and unstable friction behaviour of $\mathrm{C} / \mathrm{C}$ composites limits its applications [6]. In order to overcome these disadvantages of $\mathrm{C} / \mathrm{C}$ composites, $\mathrm{SiC}$ was incorporated in the carbon matrix to enhance its oxidation resistance and tribological performance [7]. Incorporation of SiC increases the hardness and thermal stability, and decreases the chemical reactivity which leads to the improvement of frictional properties of $\mathrm{C} / \mathrm{C}$ composites. $\mathrm{C} / \mathrm{C}-\mathrm{SiC}$ composites have high and stable COF, low wear rate, long service life and low sensitivity to surroundings and oxidation $[5,8,9]$. The mechanical properties of C/C-SiC composites don't get affected at high temperature [3]. When the weight content of silicon carbide is higher than $20 \%$ in the $\mathrm{C} / \mathrm{C}$-SiC composites, the composites show lower sensibility to surroundings and temperature [10]. C/C$\mathrm{SiC}$ composite usually possesses higher density as compared to $\mathrm{C} / \mathrm{C}$ composites [5]. This makes $\mathrm{C} / \mathrm{C}$ composite more favourable compared to $\mathrm{C} / \mathrm{C}$-SiC composites in weight sensitive applications.

Tribological behaviour of fiber reinforced composites depend on the orientation of fibres with respect to the sliding direction of counterface (i.e., parallel, antiparallel and normal) [11, 12]. Nothing can be generalized much about which orientation yields desirable tribological performance. Different types of composites yields different results. Theoretically, the tribological behaviour of a composite material 
depends upon the area proportion and local COF of different constituents with the counter surface [13]. The area proportion of different phases in a laminated composite changes with the orientation of laminates. Most of the investigations focussed on wear and friction performance of $\mathrm{C} / \mathrm{C}$ and $\mathrm{C} / \mathrm{C}-\mathrm{SiC}$ composites dealt with parallel orientation of laminates. Normal orientation effects are still not very clear. However, when the materials are investigated experimentally, so many other factors are also involved.

Tribological behaviour of $\mathrm{C} / \mathrm{C}$ and $\mathrm{C} / \mathrm{C}-\mathrm{SiC}$ composites also depend on the counter surface material to a greater extent $[6,14]$. Many researchers [15-18] had investigated the tribological behaviour of $C / C$ and $\mathrm{C} / \mathrm{C}$-SiC composites using parallel orientation of laminates in self-mated pairs. Surface conformity also effects the tribological behaviour of materials. $\mathrm{C} / \mathrm{C}$ and $\mathrm{C} / \mathrm{C}$-SiC composites are mostly investigated with fully conformal surfaces. [10,17-21]. Few researchers have conducted research using surfaces with low conformity $[14,22,23]$. The tests conducted on surfaces with full conformity differs from the tests conducted with low or non-conformal contacts [22]. Tribological behaviour of C/C and C/C-SiC composites under non-conformal Hertzian contacts have not been investigated yet. Further, most of the investigations on sliding behaviour of $\mathrm{C} / \mathrm{C}$ and $\mathrm{C} / \mathrm{C}$-SiC composites are based on high energy braking conditions. Sliding behaviour under low energy conditions have not been investigated much.

In this study, dry sliding behaviour of $\mathrm{C} / \mathrm{C}$ and $\mathrm{C} / \mathrm{C}$-SiC composites was investigated. Two orientations of laminates were considered i.e. normal and parallel orientation with respect to sliding direction of counterface. Theoretically, the overall friction and wear behaviour of a composite depend upon local friction and wear response of its different constituents whose proportions change with the orientation of laminates. Thus, preliminary guess was that the composites with parallel orientation of laminates should show higher friction coefficient and wear resistance because of higher area proportion of fibres on the contact surface. But the analysis showed that several other factors were also involved. Furthermore, low conformity and non-conformal Hertzian contacts were considered to analyze the surface conformity effect. The tests were conducted on pin/ball on disk tribometer to investigate the effect of laminate orientation and surface conformity with variation of normal load and sliding velocity. Most of the earlier investigations on tribological behaviour of $\mathrm{C} / \mathrm{C}$ and $\mathrm{C} / \mathrm{C}$-SiC composites were carried out using inertial type dynamometer. Tests conducted using open type configuration (pin/ball on disk tribometer) differ from the tests conducted using closed type configuration (inertial type dynamometer) because the escapement of wear debris from in-between the contact surfaces is difficult in closed type configuration and wear debris plays an important role the depicting the friction and wear behavior. Normal load and sliding velocity were also varied. Worn surface were analyzed under scanning electron microscope to know the dominant wear mechanisms.

\section{Experimental Details}

\subsection{Sample preparation}

Carbon/carbon (C/C) composites were received from Division of Space Propulsion, Institute of Space and Astronautical Science, 3-1-1 Yoshinadai, Sagamihara-shi, Kanagawa-ken, Japan. The 2D woven fabric 
(plain weave) $\mathrm{C} / \mathrm{C}$ composites were manufactured by reinforcing plain woven cloths of high-strength (IM600) PAN based carbon fibres ( $7 \mu \mathrm{m}$ diameter, supplied by Toho Rayon Co., Japan) in resol type phenolic resin. The resulting carbon fibre reinforced polymer (CFRP) composite was carbonized at $1000{ }^{\circ} \mathrm{C}$ and densified by repeating impregnation of phenolic resin (for six cycles) in vacuum, and carbonization. Finally the resulting composite was heat treated at $1500^{\circ} \mathrm{C}$. The obtained $\mathrm{C} / \mathrm{C}$ composite contained $50 \%$ carbon fibres by volume and $43 \%$ carbon matrix. $\mathrm{C} / \mathrm{C}$ composite was having density of $1.8 \mathrm{~g} / \mathrm{cm}^{3}$.

Carbon/carbon - silicon carbide (C/C-SiC) composites were received from MPA, University of Stuttgart, Germany. $\mathrm{C} / \mathrm{C}$ composites were used as preform for $\mathrm{C} / \mathrm{C}$-SiC composites. $\mathrm{C} / \mathrm{C}$ preforms were prepared by the method as discussed in the last section (with same type of starting materials and processing conditions, but only two cycles of phenolic resin impregnation) and siliconized by liquid silicon infiltration (LSI) process. The preforms were heated in vacuum to the temperature of $1650^{\circ} \mathrm{C}$. The molten silicon (melting point $1410^{\circ} \mathrm{C}$ ) was infiltrated though the heated preforms. Molten silicon can enter the material only through microdelaminations and segmentation cracks. Molten silicon reacted with carbon matrix and formed silicon carbide. The obtained $\mathrm{C} / \mathrm{C}-\mathrm{SiC}$ composites contained about $38 \%$ of silicon carbide and $2 \%$ free silicon by volume. The resulting $\mathrm{C} / \mathrm{C}-\mathrm{SiC}$ composites were having density of $1.95 \mathrm{~g} / \mathrm{cm}^{3}$.

After fabrication, composites were prepared in the form of pins and disks, as shown in Fig. 1. The pins were prepared for both normal as well as for parallel orientation of laminates whereas disks were prepared for only parallel orientation of laminates. The diameter of the composite pins was prepared to $9 \mathrm{~mm}$ and diameter of the disks was prepared to $80 \mathrm{~mm}$.

\subsection{Sliding wear experiments}

Friction and wear characteristics of $\mathrm{C} / \mathrm{C}$ and $\mathrm{C} / \mathrm{C}-\mathrm{SiC}$ composites were studied against chrome steel which contained $13 \%$ chromium and $1.6 \%$ carbon. For low conformity (i.e., pin on disk), and nonconformal Hertzian contacts (i.e., ball on disk), the disk and the ball, respectively, were made of chrome steel. The hardness of the chrome steel was 62 HRc. The testing for low conformity and non-conformal Hertzian contacts were performed on the same machine (TR-20LE-PHM 400, DUCOM, Bangalore, India).

Firstly, the samples were tested for the normal orientation of laminates (designated as $\mathrm{C} / \mathrm{C}$ normal and $\mathrm{C} / \mathrm{C}$-SiC normal). For this, the orientation of the fibres was kept normal to the counter surface, as shown in Fig. 2. The diameter of the prepared composite pins were $9 \mathrm{~mm}$. Sliding wear tests were conducted at five different loads (i.e., $20 \mathrm{~N}, 30 \mathrm{~N}, 40 \mathrm{~N}, 50 \mathrm{~N}, 60 \mathrm{~N}$, keeping sliding velocity fixed at $2 \mathrm{~m} / \mathrm{s}$ ) and five sliding velocities (i.e., $1 \mathrm{~m} / \mathrm{s}, 1.5 \mathrm{~m} / \mathrm{s}, 2 \mathrm{~m} / \mathrm{s}, 2.5 \mathrm{~m} / \mathrm{s}, 3 \mathrm{~m} / \mathrm{s}$, keeping load fixed at $20 \mathrm{~N}$ ). The tests were conducted for total sliding distance of $2000 \mathrm{~m}$ at ambient conditions. Before starting the tests for low conformity contacts, composites pins were slid against counter surface for a sliding distance of $4000 \mathrm{~m}$ to get maximum contact of the surface of pin with the counterface. Friction coefficient was continuously recorded automatically.. Wear loss was obtained by weighing the sample before and after the wear test using electronic weighing balance (DENVER INSTRUMENT, SI-234). 
After testing the samples for normal orientation of laminates, samples were tested for parallel orientation of laminates (designated as $\mathrm{C} / \mathrm{C}$ parallel and $\mathrm{C} / \mathrm{C}$-SiC parallel). Due to insufficient thickness of composites having parallel laminates, a pin holder made of mild steel was used so that it can be fitted into the fixture of wear test rig for testing. The inner diameter of the pin holder was $9 \mathrm{~mm}$ and the outer diameter was $11 \mathrm{~mm}$. The procedure followed for friction and wear testing was same as in the case of normal orientation of laminates. The sliding direction of composite with respect to counter surface is shown in Fig. 3.

After testing the samples for parallel orientation of laminates, testing for non-conformal Hertzian contacts was performed. For non-conformal Hertzian contacts, ball on disk (sphere on plane) arrangement was used. The disk consisted of composite sample having parallel orientation of laminates (designated as $\mathrm{C} / \mathrm{C}$ disk and $\mathrm{C} / \mathrm{C}$-SiC disk). The ball was made of chrome steel. The diameter of the ball was $10 \mathrm{~mm}$. The rest of the procedure was same as in case of normal orientation of laminates.

The results from low conformity and non-conformal contacts were reported against applied normal load and sliding velocity. However, the normal pressure generated in case of low conformity contacts was different from non-conformal Hertzian contacts, at the same load. To simplify the data for comparison purpose, the results were plotted against normal load. For low conformity contacts, the pressure corresponding to loads of $20 \mathrm{~N}, 30 \mathrm{~N}, 40 \mathrm{~N}, 50 \mathrm{~N}$ and $60 \mathrm{~N}$ were $0.31 \mathrm{MPa}, 0.47 \mathrm{MPa}, 0.63 \mathrm{MPa}, 0.78 \mathrm{MPa}$ and $0.94 \mathrm{MPa}$, respectively. For non-conformal Hertzian contacts, the average Hertzian contact pressure corresponding to loads of $20 \mathrm{~N}, 30 \mathrm{~N} 40 \mathrm{~N}, 50 \mathrm{~N}$ and $60 \mathrm{~N}$ were approximately $0.49 \mathrm{GPa}, 0.57 \mathrm{GPa}, 0.63$ $\mathrm{GPa}, 0.67 \mathrm{GPa}$ and $0.71 \mathrm{GPa}$, respectively. Each test was carried out four times for same set of variables. The temperature of ambient and relative humidity at the time of testing was $32 \pm 2{ }^{\circ} \mathrm{C}$ and $64 \%$, respectively.

\subsection{Microscopical studies}

After completion of friction and wear testing, worn surfaces were analyzed using scanning electron microscope (SEM) to study wear mechanisms. A ZEISS EVO 18 RESEARCH, $20 \mathrm{kV}$ scanning electron microscope was used to analyse worn surfaces. To analyse the worn surface of composite pins with normal orientation of laminates, the worn surface was cut from the pin in the form of tablets having $5 \mathrm{~mm}$ thickness. To analyse disks, the worn portion of the disks were cut out in the dimension of $5 \mathrm{~mm} \times$ $5 \mathrm{~mm}$. After preparing the samples for scanning electron microscopy, samples were mounted on the sample holder of SEM and analysed.

\section{Results}

\subsection{Friction response}

Representative plots of COF vs time for $\mathrm{C} / \mathrm{C}$ composite and $\mathrm{C} / \mathrm{C}$-SiC composite with normal and parallel orientation of laminates are shown in Figs. 4 and 5. 
It can be observed from Figs. 4 and 5 that COF increased with time. This rise was attributed to increase in temperature with time. The increase in temperature enhanced adhesion and abrasion of contact conjunctions and asperities on the contact surface [22]. However, fluctuations in case of composites having normal orientation of laminates were more as compared to composites having parallel orientation of laminates due to more surface pores in case of parallel laminates (Note:- The surface conditions for normal as well as parallel orientation of laminates are shown in Fig. 2 of our published article [24]). Thus the wear debris filled the pores and formed a smooth surface which led to stability of COF as the time elapsed.

It can be seen in Fig. 6 that mean COF for $\mathrm{C} / \mathrm{C}$ normal increased with increase in load beyond $30 \mathrm{~N}$. When load was varied from $20 \mathrm{~N}$ to $30 \mathrm{~N}$, mean COF decreased for C/C normal. For C/C parallel, COF increased when the load was varied from $20 \mathrm{~N}$ to $30 \mathrm{~N}$ and after that decreased up to $50 \mathrm{~N}$ load. COF for $\mathrm{C} / \mathrm{C}$-SiC normal and $\mathrm{C} / \mathrm{C}$-SiC parallel generally increased with increase in load.

It can be observed from Fig. 7 that mean COF for $\mathrm{C} / \mathrm{C}$ normal increased with increase in sliding velocity up to $2 \mathrm{~m} / \mathrm{s}$. After that it decreased for $2.5 \mathrm{~m} / \mathrm{s}$ sliding velocity and again increased for $3 \mathrm{~m} / \mathrm{s}$ sliding velocity. For C/C parallel, the COF first decreased up to $2 \mathrm{~m} / \mathrm{s}$ velocity and after that increased. COF of $\mathrm{C} / \mathrm{C}$-SiC normal decreased with increase in sliding velocity whereas, $\mathrm{COF}$ of $\mathrm{C} / \mathrm{C}$-SiC parallel increased with increase in sliding velocity.

In case of non-conformal Hertzian contacts, $\mathrm{C} / \mathrm{C}$ composites showed increase in COF up to $30 \mathrm{~N}$ load and decrease afterwards, as can be observed from Fig. 8. However for C/C-SiC disk, COF increased with increase in load. The COF of $\mathrm{C} / \mathrm{C}$-SiC disk was more than that of $\mathrm{C} / \mathrm{C}$ disk at all tested loads.

It can be observed from Fig. 9 that the COF was almost constant for $\mathrm{C} / \mathrm{C}$ disk at all tested velocities. However for $\mathrm{C} / \mathrm{C}$ - SiC disk, COF first increased up to $2 \mathrm{~m} / \mathrm{s}$ sliding velocity and then decreased afterwards. COF of $\mathrm{C} / \mathrm{C}$-SiC disk was more than that of $\mathrm{C} / \mathrm{C}$ disk for all tested velocities.

\subsection{Wear behaviour}

Wear behaviour of composites was obtained by determining the wear loss. It can be observed from Fig. 10 that wear loss of all composites increased with increase in load. However except $\mathrm{C} / \mathrm{C}$ normal, rise was steep for all when the load was increased from $50 \mathrm{~N}$ to $60 \mathrm{~N}$.

For $\mathrm{C} / \mathrm{C}$ normal, rise was steep when the load was increased from $40 \mathrm{~N}$ to $50 \mathrm{~N}$. Wear resistance of $\mathrm{C} / \mathrm{C}$ parallel was almost same as $\mathrm{C} / \mathrm{C}-\mathrm{SiC}$ normal up to $40 \mathrm{~N}$ load. Wear loss of $\mathrm{C} / \mathrm{C}-\mathrm{SiC}$ parallel was negligible up to $20 \mathrm{~N}$ load. The wear resistance of $\mathrm{C} / \mathrm{C}$-SiC parallel was highest.

It can be observed from Fig. 11 that the wear loss of $\mathrm{C} / \mathrm{C}$ normal and $\mathrm{C} / \mathrm{C}-\mathrm{SiC}$ normal first increased with sliding velocity and decreased afterwards, as the sliding velocity was increased. However, for $\mathrm{C} / \mathrm{C}$ parallel and $\mathrm{C} / \mathrm{C}$-SiC parallel, wear loss first decreased and increased afterwards.

Wear loss of $\mathrm{C} / \mathrm{C}$ normal and $\mathrm{C} / \mathrm{C}-\mathrm{SiC}$ normal was lowest at high sliding velocity. 
It can be observed from Fig. 12 that wear loss of $\mathrm{C} / \mathrm{C}$ disk was more than that of C/C-SiC disk.

The wear loss for both $\mathrm{C} / \mathrm{C}$ and $\mathrm{C} / \mathrm{C}-\mathrm{SiC}$ disks first increased up to $40 \mathrm{~N}$ load and then decreased at $50 \mathrm{~N}$ load. After that, wear loss again increased for both $\mathrm{C} / \mathrm{C}$ and $\mathrm{C} / \mathrm{C}-\mathrm{SiC}$ disks.

It can be observed from Fig. 13 that wear loss of $\mathrm{C} / \mathrm{C}$ disk was more than that of $\mathrm{C} / \mathrm{C}$-SiC disk at all tested velocities.

Wear loss for $\mathrm{C} / \mathrm{C}$ disk first increased up to $2 \mathrm{~m} / \mathrm{s}$ sliding velocity and decreased after that. However for $\mathrm{C} / \mathrm{C}$-SiC disk, wear loss increased up to $2.5 \mathrm{~m} / \mathrm{s}$ sliding velocity and then decreased.

\section{Discussion}

When the load was increased from $20 \mathrm{~N}$ to $30 \mathrm{~N}$ in case of $\mathrm{C} / \mathrm{C}$ normal, wear debris got pulverized and compacted, and formed friction film on the surface of composite which led to decrease in COF. However, when the load was increased beyond $30 \mathrm{~N}, \mathrm{COF}$ increased. This can be attributed to the accelerated formation and disruption rate of friction film at higher loads. Disruption rate was more than formation rate. Simultaneous formation and disruption of friction film can be observed in Fig. 14a.

As the sliding velocity was increased, $\mathrm{COF}$ of $\mathrm{C} / \mathrm{C}$ normal first increased up to $2 \mathrm{~m} / \mathrm{s}$ sliding velocity. After that, it decreased for $2.5 \mathrm{~m} / \mathrm{s}$ and again increased for $3 \mathrm{~m} / \mathrm{s}$. The first rise in COF was due to increase in breaking energy which led to rapid desorption of water vapour and oxygen from the contact surface [10, 25]. When the sliding velocity was increased beyond $2 \mathrm{~m} / \mathrm{s}$, further increase in braking energy led to increase in temperature due to which pulverization and compaction of wear debris was easy and continuous friction film was formed on the surface. This decreased the COF at $2.5 \mathrm{~m} / \mathrm{s}$. Again increasing the sliding velocity led to accelerated ejection of wear debris due to centrifugal force [22] which again increased the COF. Figure $14 \mathrm{~b}$ shows $\mathrm{C} / \mathrm{C}$ normal tested at $3 \mathrm{~m} / \mathrm{s}$ sliding velocity. Some broken fibres (in the form of small fragments) and carbon debris can be observed. However very less friction film was formed.

In case of $\mathrm{C} / \mathrm{C}$ parallel, the increase in COF up to $30 \mathrm{~N}$ load was due to deeper penetration asperities with increased load which increased resistance to sliding. However as the load was increased further, formation of friction film led to decrease in COF. Further increase in load led to rapid formation and disruption of friction film which led to increase in COF. Discontinuous friction film at $60 \mathrm{~N}$ load can be observed from Fig. 15a.

Formation of friction film at low sliding velocity and its accelerated rate of formation and disruption due to spreading of wear debris at higher sliding velocities [22] describes the nature of COF with increase in sliding velocity. Figure $15 \mathrm{~b}$ shows $\mathrm{C} / \mathrm{C}$ parallel at $2.5 \mathrm{~m} / \mathrm{s}$ velocity and $20 \mathrm{~N}$ load. It can be observed that at high sliding velocity, wear debris didn't pile up much on the surface. Some broken fibres were observed.

$\mathrm{C} / \mathrm{C}$ normal showed opposite friction behaviour as compared to $\mathrm{C} / \mathrm{C}$ parallel. In case of $\mathrm{C} / \mathrm{C}$ parallel, the formation of smooth surface was easy due to more surface porosity and filling up of pores by the 
generated wear debris. However in case of normal orientation of laminates, formation and disruption of friction film effected the friction film when load and sliding velocity were varied.

COF of $\mathrm{C} / \mathrm{C}$-SiC normal and $\mathrm{C} / \mathrm{C}$-SiC parallel increased as the load was increased. This was attributed to the deeper penetration of hard $\mathrm{SiC}$ and second phase Si particles into the counterface as the load was increased $[6,19,26]$. There is also free silicon in case of $\mathrm{C} / \mathrm{C}-\mathrm{SiC}$ composites which plasticizes at higher load and led to adhesion at higher loads, thereby increased COF [19]. Figure 16a shows C/C-SiC normal tested at $30 \mathrm{~N}$ load and $2 \mathrm{~m} / \mathrm{s}$ sliding velocity. SiC particles in wear debris were observed.

$\mathrm{C} / \mathrm{C}$-SiC normal showed decrease in COF when the sliding velocity was increased. As sliding velocity was increased, the formed wear debris spread more easily on the surface. Debris contained hard SiC and second phase Si particles. SiC and second phase Si particles can't be cut easily. The spread debris rolled in between the contact surfaces. Figure 17a shows $\mathrm{C} / \mathrm{C}$-SiC normal tested at $3 \mathrm{~m} / \mathrm{s}$ sliding velocity and $20 \mathrm{~N}$ load. Wear debris can be observed.

$\mathrm{COF}$ of $\mathrm{C} / \mathrm{C}-\mathrm{SiC}$ parallel increased when the sliding velocity was increased. This was due to resistance provided by breaking of fibres [22]. As the sliding velocity was increased, the particles which were ejected from the surface slid from the surface due to centrifugal force [14] and fibres directly came in contact with the counterface. The increase in braking energy due to increase in sliding velocity led to breakage of fibres. More fibres broke at higher velocities which increased COF. Broken fibres can be observed in Fig. 17b.

C/C-SiC parallel generally showed more COF as compared to C/C-SiC normal. COF of composites depend on the interaction and local COF of different constituents [13]. C/C-SiC parallel contained more proportion of $\mathrm{SiC}$ as compared to $\mathrm{C} / \mathrm{C}-\mathrm{SiC}$ normal. Thus, $\mathrm{C} / \mathrm{C}-\mathrm{SiC}$ exhibited higher COF as compared to C/C-SiC normal.

COF of $\mathrm{C} / \mathrm{C}$ disk first increased and then decreased a bit when load was increased in case of nonconformal Hertzian contacts. This was attributed to the easy formation of friction film due to localized stress regions. However for $\mathrm{C} / \mathrm{C}$-SiC disk, formation of friction film took place at moderate loads. But at high loads, SiC disrupted the formed friction film and abraded the steel ball which increased COF at high loads. The difference between COF values from low conformity contacts and non-conformal Hertzian contacts was large in case of $\mathrm{C} / \mathrm{C}$ composites as compared to $\mathrm{C} / \mathrm{C}$-SiC composites. The COF value was less in case of non-conformal Hertzian contacts as compared to low conformity contacts because the contact area in case non-conformal contacts was very much petite and generation of high and localized stresses led to easy formation of friction film which decreased COF.

Wear loss of $\mathrm{C} / \mathrm{C}$ and $\mathrm{C} / \mathrm{C}-\mathrm{SiC}$ composites increased with increase in load whether it was normal or parallel orientation of laminates. It was observed that the composites with parallel orientation of laminates showed less wear loss as compared to composites with normal orientation of laminates. This was due to more surface porosity in case of parallel orientation of laminates. Wear debris filled the pores and formed a smooth surface. However at higher sliding velocities, wear loss of composites having 
parallel orientation of laminates was more. This was because of easy spreading of wear debris at high sliding velocities due to which smooth surface formation didn't take place.

Wear loss of $\mathrm{C} / \mathrm{C}$ composites was more as compared to $\mathrm{C} / \mathrm{C}$-SiC composites in non-conformal Hertzian contacts. Figure 18a shows $\mathrm{C} / \mathrm{C}$ disk tested at $40 \mathrm{~N}$ load and $2 \mathrm{~m} / \mathrm{s}$ sliding velocity in non-conformal Hertzian contacts. It was observed that due to formation of grooves in the vicinity of contact area, wear debris didn't get escaped much. Broken fibres can also be observed. Thus at higher load, some wear debris pulverized, and the un-pulverized particles acted as third body which rolled in between the contact surfaces and decreased the wear loss at higher loads. In case of C/C-SiC composites, the wear debris contained hard SiC particles as can be observed in Fig. 18b.

$\mathrm{SiC}$ particles are hard to cut and pulverize even at high loads. Thus wear loss of C/C-SiC composites was lower than $\mathrm{C} / \mathrm{C}$ composites in non-conformal Hertzian contacts.

Wear loss in case of non-conformal Hertzian contacts was more as compared to low conformity contacts due to generation of high and localized stress regions. The pressure corresponding to the same load (as in low conformal contacts) was very much high which led to increased wear loss.

\section{Conclusion}

In the present study, the effects of surface conformity and laminate orientation on the dry sliding behaviour of carbon/carbon and carbon/carbon-silicon carbide composites were investigated by using pin/ball on disk tribometer. Normal load and sliding velocity were also varied. The important results obtained from the present study are as follows:-

1.

The friction behaviour of composites with parallel orientation of laminates was more stable as compared to normal orientation of laminates whether it was $\mathrm{C} / \mathrm{C}$ or $\mathrm{C} / \mathrm{C}$-SiC composites due to easy formation of smooth surface with time because of more surface porosity in case of parallel orientation of laminates. 2.

When the load was increased, C/C-SiC composites showed same friction behaviour for both orientations due to presence of hard SiC particles which disrupted the friction film, whereas $\mathrm{C} / \mathrm{C}$ composites showed opposite behaviour for different orientation of laminates i.e., parallel and normal orientation. 3.

$\mathrm{C} / \mathrm{C}$ and $\mathrm{C} / \mathrm{C}-\mathrm{SiC}$ composites having same orientation of laminates yielded almost same friction behaviour with increase in sliding velocity.

4.

The friction coefficient of $\mathrm{C} / \mathrm{C}$-SiC composites didn't vary much with change in surface conformity, but a large reduction was observed in case of $\mathrm{C} / \mathrm{C}$ composites for non-conformal contacts due to its low hardness as compared to $\mathrm{C} / \mathrm{C}-\mathrm{SiC}$ composites.

5 . 
Composites with parallel orientation of laminates showed less wear loss for both composites i.e., C/C and $\mathrm{C} / \mathrm{C}$-SiC composites, whereas nature of wear behaviour didn't change much with variation in laminate orientation when the load was increased.

6.

At low sliding velocities, wear loss of composites with normal orientation of laminates was more whereas at high sliding velocities, composites in parallel orientation of laminates showed more wear loss.

7.

$\mathrm{C} / \mathrm{C}$ composites showed almost 20 to 80 times increase in wear loss in case of non-conformal Hertzian contacts when compared to low conformity contacts at same load with parallel orientation of laminates. $\mathrm{C} / \mathrm{C}$-SiC composites showed up to 10 fold increase in wear loss in non-conformal Hertzian contacts.

\section{Declarations}

Acknowledgment

Authors would like to thank Central Instrumentation Facility Centre (CIFC), Indian Institute of Technology (BHU), Varanasi, India for providing the SEM facility.

\section{References}

1. Kumar P, Srivastava VK. A Review on Wear and Friction Performance of Carbon-Carbon Composites at High Temperature. Int J Appl Ceram Technol. 2016;13:702-10.

2. Xiong $X$, Wang $Y-I$, Chen Z-k, et al. Mechanical properties and fracture behaviors of $C / C$ composites with $\mathrm{PyC} / \mathrm{TaC} / \mathrm{PyC}, \mathrm{PyC} / \mathrm{SiC} / \mathrm{TaC} / \mathrm{PyC}$ multi-interlayers. Solid State Sci. 2009;11:1386-92.

3. Manocha LM. High performance carbon-carbon composites. Sadhana. 2003;28:349-58.

4. Chen JD, Chern Lin JH, Ju CP. Effect of humidity on the tribological behavior of carbon-carbon composites. Wear. 1996;193:38-47.

5. Krenkel W, Heidenreich B, Renz R. C/C-SiC Composites for Advanced Friction Systems. Adv Eng Mater. 2002;4:427-36.

6. Fan $S$, Zhang $L$, Cheng $L$, et al. Effect of braking pressure and braking speed on the tribological properties of C/SiC aircraft brake materials. Composites Science Technology. 2010;70:959-65.

7. Kumar P, Srivastava VK. Tribological behaviour of C/C-SiC composites-A review. Journal of Advanced Ceramics. 2016;5:1-12.

8. Krenkel W. C/C-SiC Composites for Hot Structures and Advanced Friction Systems. In: 27th Annual Cocoa Beach Conference on Advanced Ceramics and Composites: B: Ceramic Engineering and Science Proceedings. John Wiley \& Sons, Inc., 2008: 583-592.

9. Krenkel W, Berndt F. C/C-SiC composites for space applications and advanced friction systems. Materials Science Engineering: A. 2005;412:177-81.

10. Shu Y, Jie C, Qizhong H, et al. Effect of Braking Speeds on the Tribological Properties of Carbon/Carbon Composites. Mater Trans. 2010;51:1038-43. 
11. Nirmal U, Yousif BF, Rilling D, et al. Effect of betelnut fibres treatment and contact conditions on adhesive wear and frictional performance of polyester composites. Wear. 2010;268:1354-70.

12. Chin CW, Yousif BF. Potential of kenaf fibres as reinforcement for tribological applications. Wear. 2009;267:1550-7.

13. Smerdova O, Cayer-Barrioz J, Le Bot A, et al. Analytical Model and Experimental Validation of Friction Laws for Composites Under Low Loads. Tribol Lett. 2012;46:263-72.

14. Paris JY, Vincent L, Denape J. High-speed tribological behaviour of a carbon/silicon-carbide composite. Composites Science Technology. 2001;61:417-23.


composites. Carbon. 2011;49:4554-62.

16. Su J-m, Xiao Z-c, Liu Y-q, et al. Preparation and characterization of carbon/carbon aircraft brake materials with long service life and good frictional properties. New Carbon Mater. 2010;25:329-34.

17. Wang $H$, Zhu D, Wan F, et al. Influence of the $C / C$ preform density on tribological characteristics of C/C-SiC composites under different conditions. Ceram Int. 2014;40:16641-6.

18. Xiang C, Li M, Zhi M, et al. A reduced graphene oxide/Co3O4 composite for supercapacitor electrode. J Power Sources. 2013;226:65-70.

19. Fan $S$, Zhang $L$, Cheng $L$, et al. Wear mechanisms of the $\mathrm{C} / \mathrm{SiC}$ brake materials. Tribol Int. 2011;44:25-8.

20. Shi Q, Xiao P. Effect of pyrolytic carbon content on microstructure and tribological properties of C/C$\mathrm{SiC}$ brake composites fabricated by isothermal chemical vapor infiltration. Solid State Sci. 2012;14:26-34.

21. Policandriotes T, Filip P. Effects of selected nanoadditives on the friction and wear performance of carbon-carbon aircraft brake composites. Wear. 2011;271:2280-9.

22. Gomes JR, Silva OM, Silva CM, et al. The effect of sliding speed and temperature on the tribological behaviour of carbon-carbon composites. Wear. 2001;249:240-5.

23. Srivastava VK. Sliding Behavior of $\mathrm{C} / \mathrm{C}$ and $\mathrm{C} / \mathrm{C}-\mathrm{SiC}$ Composites in Acidic Environment-Against High Chromium Steel Disc. American Journal of Materials Science. 2011;1:103-7.

24. Kumar P, Srivastava VK. Reciprocating sliding tribology of brake oil treated carbon fiber reinforced ceramic matrix composites. Transactions of Nonferrous Metals Society of China. 2019;29:1903-13.

25. Ozcan S, Filip P. Wear of carbon fiber reinforced carbon matrix composites: Study of abrasive, oxidative wear and influence of humidity. Carbon. 2013;62:240-7.

26. Li Z, Xiao P, Xiong X, et al. Tribological characteristics of C/C-SiC braking composites under dry and wet conditions. Transactions of Nonferrous Metals Society of China. 2008;18:1071-5.

\section{Figures}




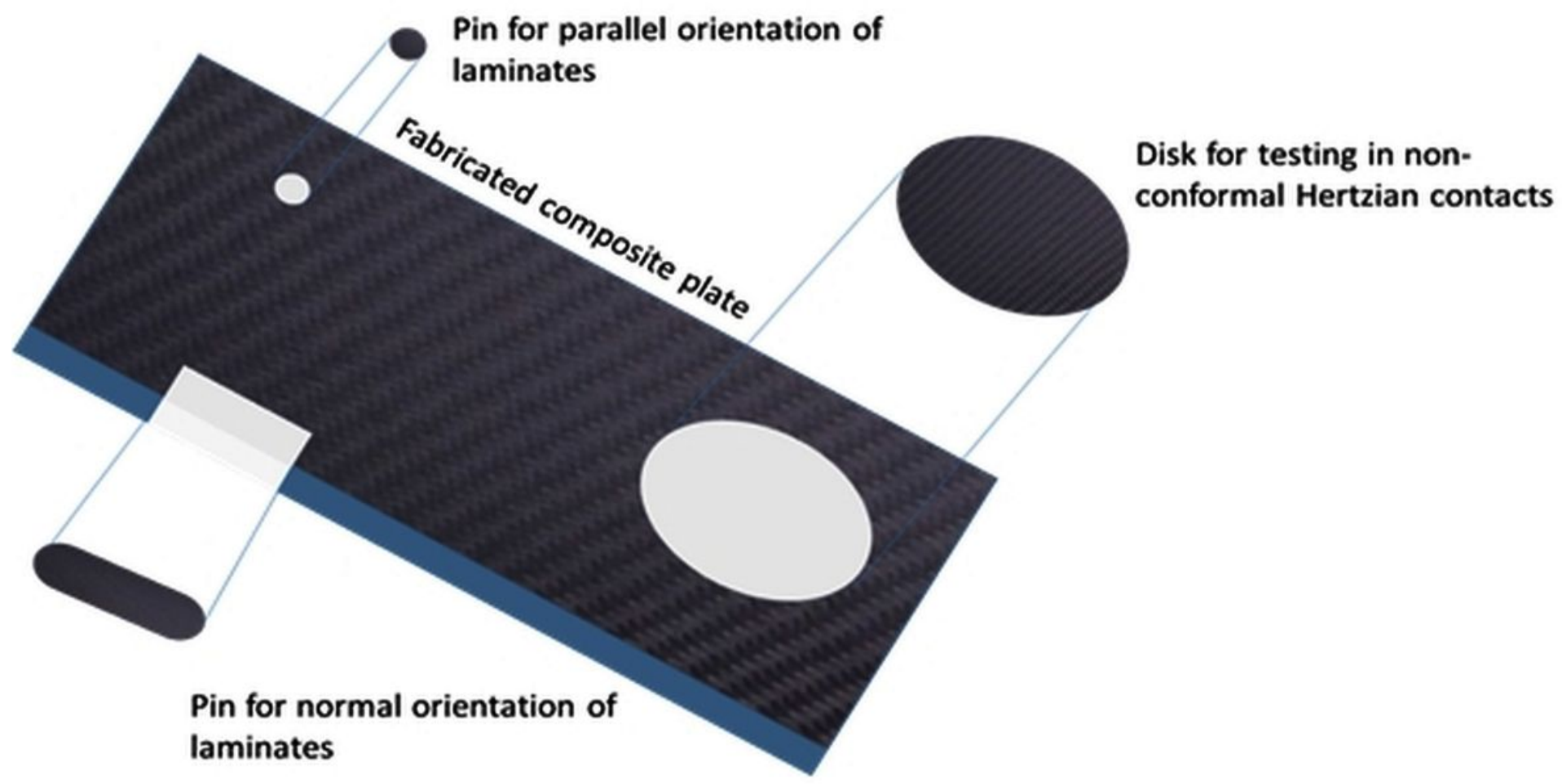

Figure 1

After fabrication, composites were prepared in the form of pins and disks, as shown in Fig. 1.



Figure 2

tThe orientation of the fibres was kept normal to the counter surface, as shown in Fig. 2.




Figure 3

The sliding direction of composite with respect to counter surface is shown in Fig. 3.


Figure 4

Representative plots of COF vs time for $\mathrm{C} / \mathrm{C}$ composite and C/C-SiC composite with normal and parallel orientation of laminates are shown in Fig. 4 and 5.


Figure 5

Representative plots of COF vs time for $\mathrm{C} / \mathrm{C}$ composite and C/C-SiC composite with normal and parallel orientation of laminates are shown in Fig. 4 and 5. 




Figure 6

It can be seen in Fig. 6 that mean COF for $\mathrm{C} / \mathrm{C}$ normal increased with increase in load beyond $30 \mathrm{~N}$. When load was varied from $20 \mathrm{~N}$ to $30 \mathrm{~N}$, mean COF decreased for C/C normal. For C/C parallel, COF increased when the load was varied from $20 \mathrm{~N}$ to $30 \mathrm{~N}$ and after that decreased up to $50 \mathrm{~N}$ load. COF for $\mathrm{C} / \mathrm{C}-\mathrm{SiC}$ normal and $\mathrm{C} / \mathrm{C}-\mathrm{SiC}$ parallel generally increased with increase in load. 




Figure 7

It can be observed from Fig. 7 that mean $\mathrm{COF}$ for $\mathrm{C} / \mathrm{C}$ normal increased with increase in sliding velocity up to $2 \mathrm{~m} / \mathrm{s}$. After that it decreased for $2.5 \mathrm{~m} / \mathrm{s}$ sliding velocity and again increased for $3 \mathrm{~m} / \mathrm{s}$ sliding velocity. For C/C parallel, the COF first decreased up to $2 \mathrm{~m} / \mathrm{s}$ velocity and after that increased. COF of $\mathrm{C} / \mathrm{C}$-SiC normal decreased with increase in sliding velocity 


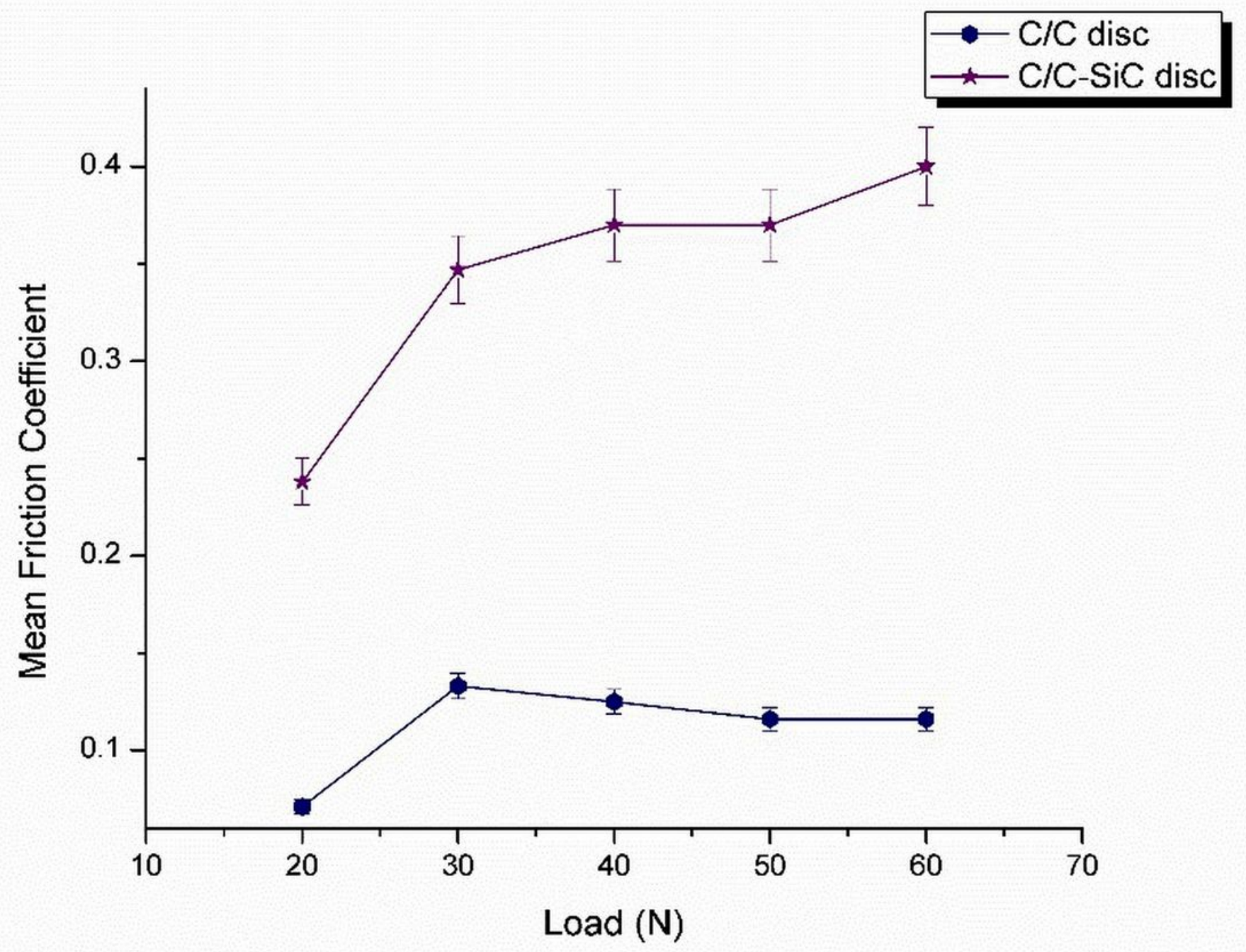

Figure 8

In case of non-conformal Hertzian contacts, $\mathrm{C} / \mathrm{C}$ composites showed increase in COF up to $30 \mathrm{~N}$ load and decrease afterwards, as can be observed from Fig. 8. 




Figure 9

It can be observed from Fig. 9 that the COF was almost constant for $\mathrm{C} / \mathrm{C}$ disk at all tested velocities. However for C/C- SiC disk, COF first increased up to $2 \mathrm{~m} / \mathrm{s}$ sliding velocity and then decreased afterwards. $\mathrm{COF}$ of $\mathrm{C} / \mathrm{C}-\mathrm{SiC}$ disk was more than that of $\mathrm{C} / \mathrm{C}$ disk for all tested velocities. 




Figure 10

Wear behaviour of composites was obtained by determining the wear loss. It can be observed from Fig. 10 that wear loss of all composites increased with increase in load. 




Figure 11

It can be observed from Fig. 11 that the wear loss of $\mathrm{C} / \mathrm{C}$ normal and $\mathrm{C} / \mathrm{C}$-SiC normal first increased with sliding velocity and decreased afterwards, as the sliding velocity was increased. However, for $\mathrm{C} / \mathrm{C}$ parallel and $\mathrm{C} / \mathrm{C}-\mathrm{SiC}$ parallel, wear loss first decreased and increased afterwards. 




Figure 12

It can be observed from Fig. 12 that wear loss of $\mathrm{C} / \mathrm{C}$ disk was more than that of $\mathrm{C} / \mathrm{C}$-SiC disk. The wear loss for both $\mathrm{C} / \mathrm{C}$ and $\mathrm{C} / \mathrm{C}$-SiC disks first increased up to $40 \mathrm{~N}$ load and then decreased at $50 \mathrm{~N}$ load. After that, wear loss again increased for both $\mathrm{C} / \mathrm{C}$ and $\mathrm{C} / \mathrm{C}-\mathrm{SiC}$ disks. 




Figure 13

It can be observed from Fig. 13 that wear loss of $\mathrm{C} / \mathrm{C}$ disk was more than that of $\mathrm{C} / \mathrm{C}$-SiC disk at all tested velocities.

Disrupted friction film

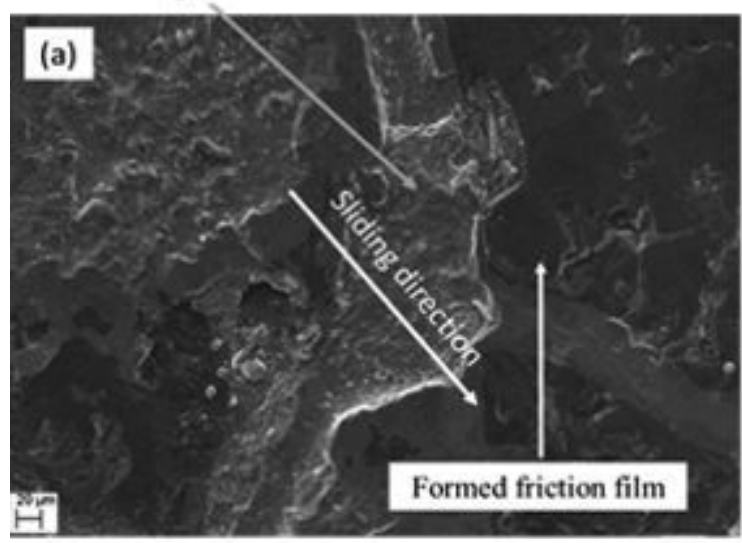

Broken fibres



Figure 14 
Disruption rate was more than formation rate. Simultaneous formation and disruption of friction film can be observed in Fig. 14a. Fig. 14b shows C/C normal tested at $3 \mathrm{~m} / \mathrm{s}$ sliding velocity. Some broken fibres (in the form of small fragments) and carbon debris can be observed. However very less friction film was formed.


\section{Figure 15}

Discontinuous friction film at $60 \mathrm{~N}$ load can be observed from Fig. 15a. Formation of friction film at low sliding velocity and its accelerated rate of formation and disruption due to spreading of wear debris at higher sliding velocities [22] describes the nature of COF with increase in sliding velocity. Fig. 15b shows $\mathrm{C} / \mathrm{C}$ parallel at $2.5 \mathrm{~m} / \mathrm{s}$ velocity and $20 \mathrm{~N}$ load. It can be observed that at high sliding velocity, wear debris didn't pile up much on the surface.


\section{Figure 16}

Fig. 16a shows $\mathrm{C} / \mathrm{C}$-SiC normal tested at $30 \mathrm{~N}$ load and $2 \mathrm{~m} / \mathrm{s}$ sliding velocity. SiC particles in wear debris were observed. Fig. 16b shows $\mathrm{C} / \mathrm{C}$-SiC parallel tested at $30 \mathrm{~N}$ load and $2 \mathrm{~m} / \mathrm{s}$ velocity. 



\section{Figure 17}

Fig. 17a shows $\mathrm{C} / \mathrm{C}-\mathrm{SiC}$ normal tested at $3 \mathrm{~m} / \mathrm{s}$ sliding velocity and $20 \mathrm{~N}$ load. Wear debris can be observed. COF of $\mathrm{C} / \mathrm{C}-\mathrm{SiC}$ parallel increased when the sliding velocity was increased. This was due to resistance provided by breaking of fibres [22]. As the sliding velocity was increased, the particles which were ejected from the surface slid from the surface due to centrifugal force [14] and fibres directly came in contact with the counterface. The increase in braking energy due to increase in sliding velocity led to breakage of fibres. More fibres broke at higher velocities which increased COF. Broken fibres can be observed in Fig. 17b.


\section{Figure 18}

Fig. 18a shows $\mathrm{C} / \mathrm{C}$ disk tested at $40 \mathrm{~N}$ load and $2 \mathrm{~m} / \mathrm{s}$ sliding velocity in non-conformal Hertzian contacts. It was observed that due to formation of grooves in the vicinity of contact area, wear debris didn't get escaped much. Broken fibres can also be observed. Thus at higher load, some wear debris pulverized, and the un-pulverized particles acted as third body which rolled in between the contact surfaces and decreased the wear loss at higher loads. In case of C/C-SiC composites, the wear debris contained hard SiC particles as can be observed in Fig. 18b. 